筆者らがこれまでに乳腺および乳腺上皮細胞での発 現を確認している16種のプロテインチロシンフォス ファターゼ(PTP)のうち(5), 12 種 (PTP1B, SHP-1, SHP-2, PTP36, HCSF, PTP-BAS, PTP $\alpha$, PTPE, LAR $\mathrm{PTP} \kappa, \mathrm{PTP} \lambda, \mathrm{PTP} \sigma)$ の発現コンストラクトをプロラ クチンレセプター, STAT5の発現コンストラクトと 上屯に $\operatorname{Cos} 7$ 細胞に導入し，プロラクチン刺激後の STAT5 のチロシンリン酸化レベルを抗リン酸化チロ シン抗体を用いて調べた。をの結果, 細胞質型PTP の一つPTP1B が STAT5 のリン酸化を著しく減少さ せることが明らかとなっだ(6)，さらに詳細に実験を進 めたところ，STAT5 の脱リン酸化にはPTP1Bのむ つフォスファターゼ活性が必須なこと, PTP1Bは STAT5aだけでなくSTAT5bをも脱りン酸化し， STAT5をりン酸化するJAK2には作用しないこと， さらにSTAT5 の細胞質加ら核内へのトランスロケ ーションを阻害することも明らかとなった。またこ れらの結果と非常によく相関し，PTP1Bは $\beta$-casein のプロモーター活性もその発現量に依存して阻害し た.

さらに，乳腺上皮細胞における PTP1B の働きを調 べるために，レトロウイルスを用いた遺伝子導入法に より乳腺上皮細胞にPTP1B およびその活性知失变異 体を導入し，安定発現株を得た。これらの細胞を用い てプロラクチンシグナリングを調べたところ， COS7 細胞を用いた再構成実験之ほぼ同様な結果が得られ た。つまり，野生型PTP1Bを導入した乳腺上皮細胞 では，プロラクチン刺激に応じた STAT5 のリン酸化 レベルが滅少し，それに呼応して内因性 $\beta$-casein
遺伝子発現が有意に抑制された。

またPTP1B substrate trapping 变異体を用いて共 沈降実験を行ったところ，チロンンリン酸化を受けた STAT5が特異的に共沈降することが明らか上なる た，また興味深いことに，STAT5だけでなくほかに あいくつかのチロシンリン酸化タンパク質が共沈降す ることも見いだした。

以上の結果より，PTP1B はSTAT5を特異的に脱 リン酸化することによりプロラクチンシグナリングを 負に制御することが明らかとなった（図）。しかしなが ら，PTP1B が唯一の負の制御因子とは考元にくく, 事実, 予備実験ながら他の PTPが異なるメカニズム でプロラクチンシグナリングを負に制御することを見 いだしている，今後はこれらを発屡させ，プロラクチ ンシグナル伝達経路の全容解明に迫りたいと考えてい る.

最㣪に，本研究に対してご援助いただきました（財） 農芸化学研究将励会に深く感謝いたします。

(1) V. L. DeVlaming: "Hormones and Evolution," ed. by E. J. W. Barrington, Academic Press, New York, 1979, pp. 349-561.

(2) J.-J. Lebrun, S. Ali, L. Sofer, A. Ullrich, and P. A. Kelly: J. Biol. Chem., 269, 14021-14026 (1996).

(3) J. N. Thje: Cell, 84, 331-334 (1996).

(4) M. H. Heim: J. Clin. Invest., 26, 1-12 (1996).

(5) N. Aoki, M. Kawamura, Y. Yamaguchi-Aoki, S. Ohira, and T. Matsuda: J. Biochem. (Tokyo), 125, 669-675 (2000).

(6) N. Aoki and T. Matsuda: J. Biol. Chem., 275, 39718-39726 (2000).

\section{遗伝子タギングによる植物の過敏感細胞死関連遗 伝子の単離とその機能解析}

\section{福井県立大学生物資源学部 石川敦司}

植物は種々の病原微生物の攻撃に対して，さまざま な防御機構を備えている，その中でも，感染部位にお ける過敏感細胞死は, 植物の防御応答機構発現過程に おいて重要な役割を担っていると考えられている(1). しかし，過敏感細胞死発現の分子機構については未だ 不明な点が多く，その解明が急が机ている。
近年, 過敏感細胞死の発現機構を明らかにする手段 として，病原微生物非存在下において細胞死を生じる 突然変異体（細胞死突然変異体）が，シロイヌナズナ, トゥモロコシ，イネなどから単離されている(2 5)。 こ れら突然变異体の解析から，過敏感細胞死は遺伝的に プログラムされたものであることが明らかになり，植 物におけるアポトーシスの代表例と考えられている. またこれら細胞死突然变異体は，その細胞死の形態か ら開始型と進行型の二つのクラスに大別される.開始 型の审然变異体は，過敏感細胞死を発現する初期過程 
Uroporphyrinogen III

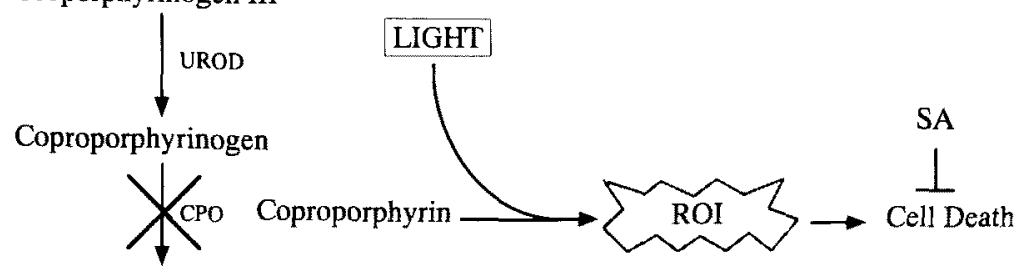

Protoporphyrinogen IX

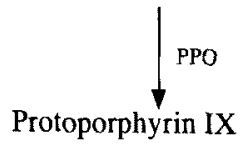

図 lin2 変異体におうおる細胞死発現のモデル

に異常をむつ変異体で，進行型の突然変異体は，細胞 死の抑制ができなくなった变異体であると考えられて いる.

現在までに多くの細胞死突然变暴体が単離されてき ているが，実際にその関与遺伝子の単離が報告されて いる例は未だ少ない．しかし細胞死発現の分子機構を 明らかにするには，これら遺伝子の単離が急務であ る。そこで申請者はシロイヌナズナのT-DNAタギン グラインをスクリーニングし，病原微生物非存在下で 細胞死を発現する突然变異体 (lin: lesion initiation) を単離してきている，它のうち lin2 変異体は，短日・ 長日雨条件下で葉に細胞死を発現したが，長日条件下 でその発現がより顕著であり，莢においても細胞死を 発現した。 lin2 変異体は劣性突然変異体であることか ら，野生株に打いて，LIN2は細胞死発現を抑制して いると考えられた．また $\operatorname{lin} 2$ 変異体では，細胞死の発 現に伴い，葉の細胞において力ロースや自家蛍光物質 の蓄積が見られるとともに，防御遺伝子 $(P R-1)$ の発 現季誘導されていたことから，過敏感細胞死発現時と 類似した現象が誘導されてることが明らかとなった。 これらの結果加ら， $\operatorname{lin} 2$ 変異体における細胞死の発現 は，植物の抵抗性反応で誘導される過敏感細胞死亡同 様な機能を有していると考えられた。

lin2 変異体は T-DNA で夕グされていると予想され たことから，TAIL-PCR 法により，その捙入部位を決 定したところ，T-DNA 第一染色体上の，ポルフィ リン合成系の酵素 coproporphyrinogen III oxidase (CPO) 遗伝子の 5'上流域に挿入されていた，次に
$\mathrm{CPO}$ 遺伝子を $\operatorname{lin} 2$ 変異体に導入したところ, 突然変 異が回復した。 また lin2 変暴体においては，CPO 遭 伝子の転写が挿入 T-DNA 領域から始まっていた。 以 上のこと加ら, $\operatorname{lin} 2$ 变異体においては, T-DNAの $\mathrm{CPO}$ 遗伝子への捙入により，異常な $\mathrm{CPO}$ 遺伝子の転 写が起こり，正常な CPOが作られないと考えられた。 またこれに伴い細胞内にポルフィリン生合成の中間 体が蓄積し，それが光を吸収して活性酸素が発生する ことにより，葉において細胞死の発現がひき起こされ たと推察された（図）。また lin2 変暴体にサリチル酸 を分解するサリチル酸ヒドロキシラーゼ (NahG) を導 入した $\operatorname{lin} 2 n a h G$ 植物体では, $\operatorname{lin} 2$ 植物体に比べて細 胞死の広がりが見られたことから， $\operatorname{lin} 2$ 植物体に扩け るサリチル酸が関与する細胞死抑制機構の存在が示唆 された(図)。

将来的には，これら過敏感細胞死関連遺伝子の発現 を人為的に制御することにより，病傷書抵抗性を付与 した植物体の創出を目指していきたい.

最後に，本研究に対しましてご援助いただきました (財)農芸化学研究奖励会に深く感謝いたします。

(1) K. E. Hammond-Kosack and J. D. Jones: Plant Cell, 8, 1773-1791 (1996).

(2) G. S. Johal, S. Hulbert, and S. P. Briggs: Bioessays, 17, 685-692 (1995).

(3) J. L. Dangl, R. A. Dietrich, and M. A. Richberg: Plant Cell, 8, 1793-1807 (1996).

(4) J.-B. Morel and J. L. Dangl: Cell Death and Differentiation, 4, 671-683 (1997).

(5) M. H. Richberg, D. H. Aviv, and J. L. Dangl, Curr. Opin. Plant Biol., 1, 480-485 (1998). 